\title{
Effect of graded levels of ginger rhizome (Zingiber officinale) meal on serum biochemistry of pubertal New Zealand White rabbits
}

\author{
Ilo, S.U. ${ }^{1}$ and Egu, U. N..$^{*}$ \\ ${ }^{1}$ Department of Animal Science, University of Nigeria Nssuka, Enugu State, Nigeria. \\ ${ }^{2}$ Department of Animal Science and fFsheries Abia State University PMB 7010 Umuahia, Nigeria. \\ *Corresponding author. Email: ucheegu1@gmail.com
}

Copyright @ 2017 llo and Egu. This article remains permanently open access under the terms of the Creative Commons Attribution License 4.0, which permits unrestricted use, distribution, and reproduction in any medium, provided the original work is properly cited.

Received 16th September, 2017; Accepted 11th October, 2017

\begin{abstract}
Forty-eight sexually matured (7 to 8 months old) healthy male and female New Zealand White rabbits were used to determine the effect of graded levels of ginger rhizome meal on serum biochemical indices. The rabbits were divided into 4 treatment groups, namely $T_{1}, T_{2}, T_{3}$ and $T_{4}$ and assigned to four treatment diets in a Complete Randomized Block Design (CRBD). Each of the treatment groups consisted of 12 rabbits (6 does and 6 bucks) replicated 3 times with 2 rabbits per replicate. The levels of inclusion of the ginger rhizome meal were $0.00,5.00,10.00$ and $15.00 \%$ for the $T_{1}, T_{2}, T_{3}$ and $T_{4}$ respectively. $T_{1}$ serves as the control. The rabbits were fed twice daily, in the morning and evening, water was given ad libitum to the rabbits. After 30 days, blood samples were collected from 12 rabbits ( 6 does and 6 bucks) in each treatment group for serum biochemical evaluation. The results showed that there were significant differences $(P<0.05)$ among the treatment groups in the serum biochemical parameters: urea (significant difference $(P<0.05)$ between rabbits on $T_{1}, T_{2}, T_{3}$ and those on $T_{4}$ ); Aspartate transaminase (significant difference $(P<0.05)$ between rabbits on $T_{2}$ and $T_{1}$; between $T_{3}$ and those on $T_{1}$ and $T_{4}$ ); Alanine transaminase (significant difference $(P<0.05)$ between rabbits on $T_{1}, T_{3}, T_{4}$ and those on $\left.T_{20}\right)$; and glucose (significant difference $(P<0.05)$ between rabbits on $T_{2}$ and those on $\left.T_{1}, T_{3}, T_{4}\right)$, except Alkaline phosphatase and cholesterol which were similar $(P>0.05)$ among the treatment groups. The results of this study indicate that inclusion of ginger rhizome meal in the diets of the rabbits up to $5 \%$ improved their serum biochemical indices.
\end{abstract}

Key words: Blood, feed, evaluation, gender, rabbits, trial.

\section{INTRODUCTION}

The common rabbit (Oryctologus cunniculus) is a species of rabbits native to south Western Europe (spain and Portugal) and north west Africa (Hoffman and Smith, 2005). The New Zealand white rabbit is an exotic breed that weighs about 4.1 to $4.5 \mathrm{~kg}$ at maturity. They have white fur that covers every part of the body with shiny eyes; they are commercial meat type and reach puberty at about 5 to 6 months of age (Egu, 2016).

The rapid increase in the world population in general and in the Nigeria population in particular has aggravated the animal protein deficiency. Food and Agricultural Organization (2006) estimated the average animal protein consumption in Nigeria to be $7.4 \mathrm{~g}$ per capita/day as compared with $38 \mathrm{~g}$ per capita/day of animal protein consumed in South Africa. The increasing demand for animal protein indicates the need to intensify livestock production. Poultry production which was the quickest way to bridge this animal protein deficiency gap was observed to be characterized by high cost of production due to high cost of feeds which accounts for more than 70 to $80 \%$ of the total production costs (Akinmutimi, 2001; Ojebiyi et al., 2006). As a result of this high cost of production in the poultry sector, most of the livestock producers are shifting to other farm animals where the cost of production is low. The rabbit was identified to possess the potential of becoming an important source of animal protein with its ability to utilize forage and cheap feedstuff efficiently. 
Ginger is an underground rhizome of the plant Zingiber officinale belonging to the family Zingiberaceae, it is considered a common constituent of diet worldwide (Bartley and Jacobs, 2000; Zhang et al., 2009). Medicinal herbs such as garlic (Allium sativum) and ginger (Zingiber officinale) have been reported to possess antibacterial, antiseptic, anti-inflammatory, anti-parasitic and immunomodulatory properties and are used for treatment of disorders of the gastrointestinal tract such as indigestion, constipation, dyspepsia, nausea and vomiting as well as rheumatism and diabetes. (Muhammad et al., 2009; Zhao et al., 2011; Afzal et al., 2001; Zhang et al., 2009; Ogbuewu et al., 2014).

Ginger extract possesses anti-oxidative characteristics, since it can scavenge superoxide anion and hydroxyl radicals (Muhammad et al., 2009). Arshad et al. (2014) reported that numerous active ingredients are present in ginger including terpenes and oleoresin which are called ginger oil. Ginger also constitutes volatile oils approximately 1 to $3 \%$ and non-volatile pungent components oleoresin (Zick et al., 2008). The major identified components from terpene are sesquiterpene hydrocarbons and phenolic compounds which are gingerol and shogaol (Hazan et al., 2012) and lipophilic rhizome extracts yielded potentially active gingerols which can be converted to shogaols and paradol (Arshad et al ., 2014). The extracts of ginger has been reported to have multiple pharmacological effects which include inhibition of prostaglandin, thromboxane and leukotrienes synthesis, inhibition of cold and platelet aggregation, cardio tonic effects, gastro-intestinal actions, thermogenic and antibiotic activities as well as digestive stimulants (Guyer, 2003). Studies have shown that ginger can be used as a natural growth promoter as it enhanced immune functions and favoured meat quality in animal (Okoye et al., 2006).

Serum biochemical analysis is used to determine the heart condition, liver and kidney functions as well as to evaluate protein quality and amino acid requirements in animals (Harper et al., 1999; Etim and Oguike, 2011). This study was carried out to determine the influence of graded levels of ginger rhizome meal on serum biochemical indices of New Zealand White rabbits and to compare this influence on their sex difference.

\section{MATERIALS AND METHODS}

\section{Location of study}

The experiment was conducted at the Rabbitory Unit of the Teaching and Research Farm of the Faculty of Agriculture, Abia State University, Umudike location near umuahia, Nigeria. This is within the south east Agro ecological zone of Nigeria and lies within latitude $5^{\circ} 29^{\prime} \mathrm{N}$ and longitude $7^{\circ} 33^{\prime} \mathrm{E}$ and at an altitude of $122 \mathrm{~m}(400$ feet) above sea level. The area has an annual ambient temperature of $253^{\circ} \mathrm{C}$, relative humidity between 65 to
$89 \%$, annual rainfall 2000 to $2484 \mathrm{~mm}$ and the soil is sandy loamy with average pH 5.5 (Adiele et al., 2005).

\section{Experimental animals and their management}

Forty eight sexually matured male and female New Zealand White rabbits aged 7 to 8 months were used for this experiment. The rabbit bucks have an average weight of $1200.00 \mathrm{~g}$ whereas the rabbit does have an average weight of $1250.00 \mathrm{~g}$. Each animal was housed in a clean, well ventilated single hutch of $50 \times 50 \mathrm{~cm}^{2}$ with wire mesh floor and wooden frames. They were acclimatize for 2 weeks and fed with commercial concentrate diet (Top Grower Mash) containing 16.00\% crude protein and $2450 \mathrm{Kcal} / \mathrm{kg}$ metabolizable energy. Each hutch was tagged for easy identification. The animals were dewormed before the commencement of the experiment. The experimental period lasted for complete 30 days.

\section{Processing of ginger rhizome meal}

Fresh rhizomes of ginger (Zingiberofficinale) were sourced from Ogbete market in Enugu, Enugu State, Nigeria. The fresh ginger rhizomes were washed in water to remove dirt. Their sizes were reduced, sun dried, milled to fine powder, sieved using $2.5 \mathrm{~mm}$ test sieve and formulated into diet.

\section{Experimental diets and design}

Four experimental diets namely $T_{1}, T_{2}, T_{3}$ and $T_{4}$ were formulated. $T_{1}$ had no ginger rhizome meal hence serves as the control $(0 \%)$ while $T_{2}, T_{3}$ and $T_{4}$ contained 5,10 and $15 \%$ ginger rhizome meal respectively. Freshly cut forage consisting of Panicum maximum, Pennisetum purpureum and Centrosema pubescenswas fed as basal diet. The animals were fed $700 \mathrm{~g}$ of forage and $1 \mathrm{~kg}$ of concentrate twice daily. Water was provided ad libitum and multivitamin drugs were given to them through drinking water to boost their immunity against infections. The chemical composition of the forages and the nutrient composition of the experimental diet are shown in Tables 1 and 2 respectively. A randomized complete block design was used to assign the animals to the experimental diets such that there were 12 rabbits $(6$ bucks and 6 does) replicated three times with 4 rabbits (2 does, 2 bucks) per replicate on each diet. The rabbits were fed the test diets for 30 days after which blood samples were collected and evaluation carried out.

\section{Blood collection and serum biochemical evaluation}

Four (4) rabbits (2 does, 2bucks) from each replicate, making a total of 12 rabbits (6 does, 6 bucks) per treatment were selected for bleeding. $3 \mathrm{ml}$ of blood was 
Table 1. Chemical composition of the forages (\%).

\begin{tabular}{lccc}
\hline Parameters & CP & PM & PP \\
\hline Dry matter & 73.38 & 85.30 & 73.69 \\
Crude protein & 25.20 & 9.79 & 7.87 \\
Ether extract & 3.34 & 1.20 & 2.59 \\
Ash & 7.89 & 8.10 & 8.51 \\
Crude fibre & 8.10 & 8.70 & 8.50 \\
Nitrogen free extract & 33.53 & 41.60 & 42.40 \\
ME (MJ/Kg DM) & 0.93 & 1.46 & 1.20 \\
\hline
\end{tabular}

PM, Panicum maximum, PP, Pennisetum purpereum, CP, Centrosema pubescens, ME, metabolizable energy, $\mathrm{MJ} / \mathrm{Kg}$, DM, mega joule/kilogram dry matter.

Table 2. Composition of experimental diets.

\begin{tabular}{lcccc}
\hline \multirow{2}{*}{ Ingredients } & $\mathbf{T}_{\mathbf{1}}$ & $\mathbf{T}_{\mathbf{2}}$ & $\mathbf{T}_{\mathbf{3}}$ & $\mathbf{T}_{\mathbf{4}}$ \\
\cline { 2 - 5 } & $\mathbf{0 \%}$ & $\mathbf{5 \%}$ & $\mathbf{1 0 \%}$ & $\mathbf{1 5 \%}$ \\
\hline Maize & 40 & 40 & 40 & 40 \\
Ginger meal & - & 5 & 10 & 15 \\
Wheat offal & 15 & 10 & 5 & - \\
P.K.C & 14 & 14 & 14 & 14 \\
S.B.M & 22 & 22 & 22 & 22 \\
Fish meal & 2 & 2 & 2 & 2 \\
Oyster shell & 2.5 & 2.5 & 2.5 & 2.5 \\
Bone meal & 3.0 & 3.0 & 3.0 & 3.0 \\
Methionine & 2.5 & 2.5 & 2.5 & 2.5 \\
Lysine & 2.5 & 2.5 & 2.5 & 2.5 \\
Vitamin / Premix & 2.5 & 2.5 & 2.5 & 2.5 \\
Salt & 0.5 & 0.5 & 0.5 & 0.5 \\
Mycofix & 0.25 & 0.25 & 0.25 & 0.25 \\
Total & 100 & 100 & 100 & 100 \\
Calculated analysis & & & & \\
Crude protein \% & 20.01 & 19.79 & 19.57 & 19.36 \\
ME (Kcal / kg) & $2,747.62$ & $2,771.67$ & $2,808.84$ & $2,846.01$ \\
\hline
\end{tabular}

ME, Metabolizable energy, Kcal/Kg, kilocal/kilogram, PKC, Palm kernel cake, SBM, Soyabean meal.

aspirated from the marginal ear vein of each rabbit using needle and syringe for serum biochemical evaluation. They were transferred into Plain bottles and allowed to coagulate. The coagulated blood was subjected to standard methods of serum separation and the harvested sera were used for evaluation of serum biochemical parameters: urea, cholesterol and glucose were determined according to the methods described by Baker and Silverton (1986). Aspartate transaminase, Alanine transaminase and Alkaline phosphatase activities were determined using spectrophotometric method as described by Rej and Hoder (1983). The standard flame photometry method using Gallenkamp analysis was used to determine serum calcium.

\section{Data Analysis}

Data obtained on serum biochemical indices of the male and female rabbits were subjected to analysis of variance (ANOVA) with Dunnett's control test using the SPSS (1996) package. Significant treatment means were separated using Duncan's New Multiple Range Test as described by Obi (2002). Statistical differences between sexes were determined by students't-test. The analysis is considered significant at $\mathrm{P}<0.05$.

\section{RESULTS AND DISCUSSION}

The results of serum biochemical parameters of New 
Table 3. Serum biochemical parameters of New Zealand white rabbits fed graded levels ginger rhizome meal.

\begin{tabular}{|c|c|c|c|c|c|}
\hline \multirow{3}{*}{ Parameters } & \multicolumn{4}{|c|}{ Dietary Levels (\%) } & \multirow{3}{*}{ SEM } \\
\hline & $T_{1}$ & $T_{2}$ & $T_{3}$ & $T_{4}$ & \\
\hline & 0.0 & 5.0 & 10.0 & 15.0 & \\
\hline Urea $(\mathrm{mmol} / \mathrm{l})$ & $12.42^{\mathrm{a}}$ & $12.42^{\mathrm{a}}$ & $12.04^{\mathrm{a}}$ & $10.34^{\mathrm{b}}$ & 0.41 \\
\hline AST (iu/l) & $24.68^{c}$ & $34.90^{\mathrm{ab}}$ & $38.96^{\mathrm{a}}$ & $26.89^{b c}$ & 2.98 \\
\hline ALT (iu/l) & $31.35^{\mathrm{a}}$ & $24.13^{b}$ & $28.89^{a}$ & $28.96^{a}$ & 1.31 \\
\hline ALP (iu/l ) & 48.12 & 56.30 & 44.25 & 51.38 & 7.77 \\
\hline Cholesterol $(\mathrm{mg} / \mathrm{dl})$ & 2.13 & 2.46 & 2.63 & 1.47 & 0.33 \\
\hline Glucose $(\mathrm{mmol} / \mathrm{l})$ & $102.22^{b}$ & $139.83^{a}$ & $110.45^{b}$ & $91.15^{\mathrm{b}}$ & 8.33 \\
\hline Calcium $(\mathrm{mmol} / \mathrm{l})$ & $14.22^{\mathrm{a}}$ & $13.54^{\mathrm{a}}$ & $13.23^{a}$ & $11.99^{b}$ & 0.38 \\
\hline
\end{tabular}

a,ab,b,bc,c:Means within the same row with different superscripts are significantly $(P<0.05)$ different. SEM, Standard Error of means $A L P$, Alkaline phosphatase, ALT, Alanine transaminase, AST, Aspartate transaminase.

Zealand White rabbits fed graded levels of ginger rhizome meal are shown in Table 3. There were no significant differences $(P>0.05)$ among the treatment groups in the mean values of Alkaline phosphatase (ALP) and cholesterol, but there were significant differences $(P<0.05)$ among the treatment groups in the mean values of urea, Aspartate transaminase (AST), Alanine transaminase (ALT), glucose and calcium

Urea values obtained in this study ranged from 19.34 to $12.42 \mathrm{mmol} / \mathrm{l}$. Rabbits on $\mathrm{T}_{1}$ and $\mathrm{T}_{2}$ had the highest urea value of $12.42 \mathrm{mmol} / \mathrm{l}$ and this differed significantly $(P<0.05)$ from rabbits on $T_{4}$. There were no significant differences $(P>0.05)$ among rabbits on $T_{1}, T_{2}$, and $T_{3}$ in urea values. The least value of $10.34 \mathrm{mmol} / \mathrm{l}$ in urea was observed in rabbits on $\mathrm{T}_{4}$. The result followed a decreasing trend from $T_{1}$ to $T_{4}$. The result of this study agreed with the normal reference range of 10.00 to 33.00 $\mathrm{mmol} / \mathrm{l}$ reported by University of Pennsylvania School of Veterinary Medicine (2002) and Merck (2012). The normal blood urea values obtained in this trial were indication that the amino acid of the test diets was balanced. It has been reported that serum urea content depends on both the quantity and quality of protein supplied in the diet (Iheukwumere and Herbert, 2002).

Aspartate transaminase (AST) values ranged from 24.68 to $38.96 \mathrm{iu} / \mathrm{l}$. Rabbits in $\mathrm{T}_{3}$ had the highest value of $38.96 \mathrm{iu} / \mathrm{l}$ and this differed significantly $(P<0.05)$ from rabbits on $T_{1}$ and $T_{4}$ which were similar $(P>0.05)$ to each other in AST value. Rabbits on $\mathrm{T}_{4}$ were similar $(\mathrm{P}>0.05)$ to those on $T_{2}$ in AST value. Similarly, there was no significant difference $(P>.05)$ between rabbits on $T_{3}$ and $\mathrm{T}_{2}$ in AST values. The result followed an increasing trend from $T_{1}$ to $T_{3}$ and later decreased significantly in $T_{4}$. The values of AST obtained in this study were within the normal range of healthy rabbits 10 to $120 \mathrm{iu} / \mathrm{l}$ as reported by University of Pennsylvania School of Veterinary Medicine (2002). However, the values of AST obtained in this study were higher than the range of 7.73 to $16.0 \mathrm{iu} / \mathrm{l}$ reported by Ahamefule et al., (2006). They fed weaner rabbits sundried, ensiled and fermented cassava peel based diets. This disparity may not be unconnected to age and nutritional status of the rabbits. Analysis of liver enzymes (AST, ALT, and ALP) activities give valuable diagnostic information for a number of disease conditions.

Alanine transaminase (ALT) values ranged from 24.13 to $31.35 \mathrm{iu} / \mathrm{l}$. The highest value of $31.35 \mathrm{iu} / \mathrm{l}$ was recorded in rabbits on $T_{1}$ and this differed significantly $(P<0.05)$ from rabbits on $T_{2}$. There were no significant differences ( $P>0.05$ ) among rabbits on $T_{1}, T_{3}$ and $T_{4}$ in ALT values. The least ALT value of $24.13 \mathrm{iu} / \mathrm{l}$ was observed in rabbits on $T_{2}$. The values of ALT obtained in this study agreed with the normal range of 10.00 to 45.00 (iu/l) reported by Merck (2012). However, the values of ALT obtained in this study disagreed with the range 9.17 to $12.80 \mathrm{iu} / \mathrm{l}$ reported by Ahamefule et al. (2006), they fed rabbits with sundried, ensiled and fermented cassava peel based diets. The normal value of ALT obtained in this study indicates that the activities of osteoblast were not affected because the blood level of ALT is usually a good indicator of the rate of bone formation.

Alkaline phosphate (ALP) values ranged from 44.25 to $56.30 \mathrm{iu} / \mathrm{l}$. The highest numerical value of $56.30 \mathrm{iu} / \mathrm{l}$ was recorded in rabbit on $\mathrm{T}_{2}$ followed by $\mathrm{T}_{4}(51.38 \mathrm{iu} / \mathrm{l}), \mathrm{T}_{1}$ (48.12 iu/l) and T3 (44.25 iu/l) which had the least value in ALP. The values of ALP obtained in this study agreed with the range of 17.00-192.00 (iu/l) reported by (Merck, 2010). The ALP values obtained in this study did not follow any given pattern. Moreso, the values obtained differ with the range 5.92 to 8.38 iu/l reported by Ewuola et al. (2010), who fed weaner rabbits using dietary prebiotics and probiotics. The disparity may not be unconnected with the differences in physiological factors of these rabbits. Alkaline phosphatase assay is useful in the diagnosis of obstructive liver diseases (Murray et al., 2003). The liver is the organ involved in the detoxification of xenobiotics and other harmful chemicals that gain entrance into the body (Murray et al., 2003). An increase in alkaline phosphatase, alanine transaminase and aspartate transaminase values would signify necrosis or 
Table 4. Effect of sex on serum biochemical parameters of New Zealand white rabbits fed graded levels of ginger rhizome meal.

\begin{tabular}{lccc}
\hline Parameters & Male & Female & SEM \\
\hline Urea $(\mathrm{mmol} / \mathrm{l})$ & $12.66^{\mathrm{a}}$ & $10.94^{\mathrm{b}}$ & 0.28 \\
AST $(\mathrm{iu} / \mathrm{l})$ & 32.98 & 29.74 & 2.11 \\
ALT $(\mathrm{iu} / \mathrm{l})$ & $31.31^{\mathrm{a}}$ & $25.36^{\mathrm{b}}$ & 0.93 \\
ALP $(\mathrm{iu} / \mathrm{l})$ & 52.91 & 47.11 & 5.49 \\
Cholesterol $(\mathrm{mg} / \mathrm{dl})$ & 1.88 & 2.46 & 0.23 \\
Glucose $(\mathrm{mmol} / \mathrm{l})$ & $138.19^{\mathrm{a}}$ & $83.63^{\mathrm{b}}$ & 6.22 \\
Calcium $(\mathrm{mmol} / \mathrm{l})$ & 13.07 & 13.42 & 0.27 \\
\hline
\end{tabular}

a,b:Means within the same row with different superscripts are significantly $(P<0.05)$ different. SEM, Standard Error of means. ALT, Alanine transaminase; AST, Aspartate transaminase; ALP, Alkaline phosphates.

myocardial infarction which are all indicators of drug toxicity or harmful chemicals in the body (Nelson and Cox, 2005).

Serum cholesterol values ranged from 1.47 to 2.63 $\mathrm{mg} / \mathrm{dl}$. Rabbits on $\mathrm{T}_{3}$ recorded the highest numerical value of $2.63 \mathrm{mg} / \mathrm{dl}$ in serum cholesterol followed by $\mathrm{T}_{2}$ $(2.46 \mathrm{mg} / \mathrm{dl}), \mathrm{T}_{1}(2.13 \mathrm{mg} / \mathrm{dl})$ and $\mathrm{T}_{4}$ which had the least value of $1.47 \mathrm{mg} / \mathrm{dl}$ in serum cholesterol. The values increased progressively from $T_{1}$ to $T_{3}$ and got reduced at $\mathrm{T}_{4}$. As dietary levels of ginger increased from 5 to $10 \%$, the cholesterol value increased. Mufwa et al. (2011) and Mohammed et al. (2014) reported higher values (33.12 to $40.00 \mathrm{mg} / \mathrm{dl})$ and ( 48.44 to $49.11 \mathrm{mg} / \mathrm{dl})$ respectively. The values of cholesterol obtained in this study were slightly above the range of 0.30 to 2.10 reported by Merck (2012). It could be that ginger rhizome meal (5 to 10\%) increased metabolism and efficient utilization of fat that led to increased cholesterol values in the serum. Cholesterol in the serum has been associated with the quantity and quality of fat supplied in the diet (Esonu et al., 2001).

Glucose values ranged from 91.15 to $139.83 \mathrm{mmol} / \mathrm{l}$. Rabbits on $\mathrm{T}_{2}$ recorded the highest glucose value of $139.83 \mathrm{mmol} / \mathrm{l}$ and this differed significantly $(\mathrm{P}<0.05)$ from rabbits on $T_{1}(102.22 \mathrm{mmol} / \mathrm{l}), T_{3}(110.45 \mathrm{mmol} / \mathrm{l})$ and $T_{4}$ $(91.15 \mathrm{mmol} / \mathrm{l})$ which were similar $(P>0.05)$ to each other in glucose values. The glucose values obtained in this study did not agreed with the findings of Ewuola et al. (2012) who reported a higher glucose range of 114.00 to $142.00 \mathrm{mmol} / \mathrm{l}$ when fed rabbit with graded levels of Moringa oleifera leaf meal. The result agreed with the range of 80 to $150 \mathrm{mmol} / \mathrm{l}$ reported by Mufwa et al. (2011) and University of Pennsylvania School of Veterinary Medicine (2012). Glucose is one of the metabolites measured as an indicator of the energy status of animals. Normal glucose levels in rabbits indicate adequate synthesis in the liver from propionate metabolism as the major glucose precursor (Sowande et al., 2008). The study also indicates that there was no wasting or catabolism of muscle tissue and that rabbits were not surviving at the expense of body reserve.
Serum calcium values ranged from 11.99 to 14.22 $\mathrm{mmol} / \mathrm{l}$. Rabbits on $\mathrm{T}_{1}$ had the highest value of 14.22 $\mathrm{mmol} / \mathrm{l}$ in serum calcium and this differed significantly $(\mathrm{P}<0.05)$ from rabbits on $\mathrm{T}_{4}$ which had the lowest value of $13.23 \mathrm{mmol} / \mathrm{l}$. There were no significant differences ( $P>0.05$ ) among rabbits on $T_{1} T_{2}$, and $T_{3}$ in serum calcium values. The values decreased progressively from $\mathrm{T}_{1}$ to $\mathrm{T}_{4}$. The serum calcium values obtained in this study agreed with the result of Mohammed et al. (2014) in rabbits, and were within the normal calcium range (8.00 to 15.50) reported by University of Pennsylvania School of Veterinary Medicine (2002). However, calcium values obtained in this study were higher than the range of $3.01 \pm 0.09$ to $2.50 \pm 3.72$ reported by Ozkan et al. (2012) in New Zealand White rabbits. The serum calcium plays a vital role in bone formation and structure as they constitute the major mineral content that helps in the formation and strengthening of bones. It also mediates in excitation and contraction of muscle fibre (Banerjee, 2007).

The results of serum biochemistry of male and female New Zealand White rabbits fed graded levels of ginger rhizome meal are shown in Table 4. There were significant differences $(P<0.05)$ between the treatment groups in urea, ALT and glucose. Conversely, there were no significant differences $(P>0.05)$ between the treatment groups in AST, ALP, cholesterol and calcium. The results also revealed that all the serum biochemical indices of the male rabbits were higher than the female rabbits except for cholesterol and calcium. The result agreed with the range reported by University of Pennsylvania School of Veterinary Medicine (2002), Ozkan et al. (2012) and Merck (2012). Biochemical components are sensitive to elements of toxicity and also can be used to monitor protein quality of feeds. It also signifies proper functioning of some internal organs.

\section{Conclusion}

The results of this study have shown that ginger rhizome 
meal can bring about improvement of serum biochemical parameters of the pubertal male and female rabbits at the inclusion level of $5 \%$.

\section{CONFLICT OF INTEREST}

The authors declare that they have no conflict of interest.

\section{REFERENCES}

Adiele, J. G., Audu, H. O., Madu, T., \& Nwaogwugwu, R. O. (2005). Weather in 2005 at Umudike and its possible Impact on root crops production. National Root Crops Research Institute Annual Report for 2005, Pp.252-255.

Afzal, M., Al-Hadili, D., Menon, M., Pesek, L., \& Dhami, M. S. C. (2001). Ginger: an ethnomedicinal, Chemical and pharmacological review. Drug Metab. Drug Interact., 18, 159190.

Ahamefule, F. O, Eduok, G. O., Usman, A., Amaefule, K. U., Obua, B. E., \& Oguike, S. A. (2006). Blood Biochemistry and Haematology of Weaner Rabbits Fed Sundried, Ensiled and Fermented Cassava Peel Based Diets. Pakistan Journal of Nutrition, 5(3), 248-253.

Akinmutimi, A. H. (2001). The Effect of Potash-Cooked lima bean (Phaseoluslunatus) on Broiler Starter Diets. Nig. Agri. J., 32, 109-118.

Arshad, H. R., Fahad, M. A., \& Salah, M. A. (2014). Active ingredients of ginger as potential candidates in the prevention and treatment of diseases via modulation of biological activities. Int. J. Physiol. Pathophysiol. Pharmacol., 6(2), 125136.

Baker, F. J., \& Silverton, R. F. (1986).Introduction to Medical Laboratory Technology $6^{\text {th }}$ Edn. Buther-Worth England.

Banerjee, G. C. (2007). A Textbook of Animal Husbandry (8 ${ }^{\text {th }}$ edition) Oxford and IBH Publishing co PVT Ltd New Delhi India.

Bartley, J., \& Jacobs, A. (2000). Effects of drying on flavour compounds in Australian grown ginger (Zingiberofficinale). J. Sci. Food and Agric., 80, 209-215.

Egu, U. N. (2016). Effect of gonadotrophin (Diclair $\left.{ }^{\circledR}\right)$ on semen characteristics, body conformation and hormonal profile of mature male Nw Zealand White rabbits. Inter J. Agric. Biosci, 4(6), 260-265.

Esonu, B. O., Emenalom, O. O., Udedibie, A. B. I., Herbert, U., Ekpor, C., \& Iheukwumere, F. C, (2001). Performance and Blood Chemistry of Weaner Pigs Fed Raw Mucuna Bean Velvet Bean Meal. Trop. Anim. Prod. Invest., 4, 49-54.

Etim, N. N., \& Oguike, M. A. (2011).Haematology and Serum Biochemistry of Rabbits Does Fed Aspilia Africana. Nigerian Journal of Agriculture, Food and Environment, 7(4), 121-127.

Ewuola, E. O., Jimoh, O. A., Atuma, O. V., \& Soipe, O. D. (2012). Haematological and serum biochemical responses of growing rabbits fed graded levels of Moringaoleiferaleaf meal. Proceedings 10 th World Rabbit Congress - September $3^{\text {rd }}$ $6^{\text {th }}-$ Sharm El- Sheikh -Egypt, 679-683.

Ewuola, E. O., Sokunbi, A. O., Alaba, O., Omotosho, J. O., \& Omoniyi, A. B. (2010). Haematology and serum biochemistry of weaned rabbits fed dietary prebiotics and probiotics. In: Proceedings of $35^{\text {th }}$ Conf. of Nig Society for Anim. Prod. $14^{\text {th }}$. $17^{\text {th }}$ March, University of lbadan.

FAO (2006).Food and Agricultural Organization Statistical Data
Base. Rome, Italy. Pp. 234-236.

Guyer, D. (2003). Advanced Medical Centre. Zionsville, Indian, Indianapolis, U.S.A. http://www.daleguyermd.com/glossary/Gingerhtml.

Harper, A. F., Rodwell, V. W., \& Mayes, P. A. (1999). Review of Light and breeding schedule on rabbit performance. Journal of Appl. Rabbit Res. 5, 33-37.

Hazan, H. A., Rasheed Raauf, A. M., Abd Razik, B. M., \& Rassool Hassan, B. A. (2012). Pharmaceut Chemical Composition and Antimicrobial Activity of the Crude Extracts Isolated from Zingiber Officinale by Different Solvents. Pharmaceute Anat Acta. 3,184.

Hoffman, R. S., \& Smith, A. T. (2005). Order "Lagomorpha" in Willson D.E. Reader, D.M Mammal of the World. Pp. 205206.

Iheukwumere, F. C., \& Herbert, U. (2002). Physiological responses of broiler chickens to quantitative water restriction: Haematology and serum biochemistry. International Journal of Poultry Science, 2(2), 117-119.

Merck, (2010). The Merck Veterinary Manual. $10^{\text {th }}$ Edition Merck and Co., Inc. White House Station N. J., USA. Pp. 14701492.

Merck, (2012). The Merck Veterinary Manual. $12^{\text {th }}$ Edition Merck and Co. Inc. White House Station N.J., U S A. Pp.1470-1492.

Mohammed, G., Igwebuike, J. U., Adamu, S. B., Alade, N. K., \& Asheikh, L. G. (2014). Effect of Feeding Different BloodRumen Content Mixtures on Blood Parameters and Carcass Measurements of Growing Rabbits. International Journal of Science and Nature, 5(1), 61-66.

Mufwa, B. J., Yakubu, B., Kibon, A., \& Zaklag, D. U. (2011). Haematological and Biochemical Indices of Growing Rabbit FedGraded Levels of Brewers Dried Grains. Journal of Agriculture and Veterinary Sciences. 3, 13-19.

Muhammad, J., Durrani, F., Hafeez, A., Khan, R. U., \& Ahmad, I. (2009). Effect of aqueous extract of plant mixture on carcass quality of broiler chicks Journal of Agriculture and Biological Science. Pp. 956-59

Murray, R. K., Granner, D. R., Mayes, P. A., \& Rodwell, V. W. (2003).Herper's Illustrated Biochemistry. 26 ${ }^{\text {th }}$ Edn. McGraw Hill Companies, inc. USA, p. 693.

Nelson, D. L., \& Cox, M. M. (2005).Lehninger Principles of Biochemistry. 4th Edn. W. H. Freeman and Company New York, p. 119

Obi, I. U. (2002). Statistical Methods of Detecting Differences between treatment means, 16th edition, Snapp Press, Enugu, Nigeria.

Ogbuewu, I. P., Jiwuba, P. D., Ezeokeke, C. T., Uchegbu, M. C., Okoli, I. C., \& Iloeje, M. U. (2014). Evaluation of phytochemical and nutritional composition of ginger rhizome powder.Int'I Journal of Agric and Rural Rural Dev., 17(1), 1663-1670.

Ojebiyi, O. O., Farinu, G. O., Togun, V. A. Akinlade, J. A., Aderininola, O. A., \& Rafiu, T. A. (2006). Effect of quantitative concentrate reduction on the growth of weaned rabbits. Proc. of the 11th Annual Conf. of Animal Science Association of Nigeria. 121-125.

Okoye, F. C., Ugwueme, M. C., \& Mbarab, J. U. (2006). Effect of local species on the utilization of cassava peel meal based diets by weaner rabbits. Parkistan Journal of Nutrition. 5(3), 202-205.

Ozkan, C., Kaya, A., \& Akgül, Y. (2012).Normal values of haematological and some biochemical parameters in serum and urine of New Zealand White rabbits. World Rabbit Sci. 20, 253-259. 
Rej, R., \& Hoder, M. (1983). Alanine Transaminase. In: Methods of EnzymaticAnalysis 3rd Edition Bergmeyer, H. U., Berg, I. \& Grassal, M. (eds). WeinhenVelag. Chemie 1, 3416433.

Sowande, O. S., Aina, A. B. J., Oguntona, E. B., Fanimo, A. O., Unaka, V. U., Itassan, T. A., \& Oseni, M. O. (2008). Performance, blood biochemical constituents and mineral balance of West African Dwarf Sheep fed preserved Elephant grass, Layer's droppings and cassava peel diet during dry season. Nig. J. Anim. Prod. 35(1), 90-102.

SPSS (1996). Statistical package for social Sciences. SPSS/STAT version 7.5 for windows.

University of Pennsylvania School of Veterinary Medicine (2002). Rabbit reference range.
Zhang, G. F., Yang, Z. B., Wang, Y., Yang, W. R., Jiang, S. Z., \& Gai, G. S. (2009). Effect of ginger root (Zingiberofficinale) processed to different particle sizes on growth performance, antioxidant status, and serum metabolites of broiler chickens. Poultry Science 88, 2159-2166.

Zhao, X., Yang, Z. B., Yang, W. R., Wang, Y., Jiang, S. Z., \& Zhang, G. G. (2011). Effects of ginger root on laying performance and antioxidant status of laying hens and on dietary oxidation stability. Poult. Sci., 90, 1720-1727.

Zick, S. M., Djuric, Z., Ruffin, M. T., Litzinger, A. J., Normolle, D. P., Alrawi, S., Feng, M. R., \& Brenner, D. E. (2008). Pharmacokinetics of 6-gingerol, 8-gngerol, 10-gingerol, and 6-shogaol and conjugate metabolites in healthy human subjects. Cancer Epidemiol Biomarkers Prev. 17, 1930-1936. 